\title{
Construction of Students Innovation and Entrepreneurship Education System
}

\author{
Shuo YANG \\ Jinlin Business and Technology College, China \\ yangyu1983@sina.com
}

Keywords: Manufacture in China, Innovation and Entrepreneurship, Education System.

\begin{abstract}
Against a background of Manufacture in China 2025, China puts forward the basic policies of "innovation-driven, quality first, green development, optimized structure and people-oriented". The innovation-driven ranks the first, showing the importance of innovation. College students are the main participants for further development of manufacture, of which the innovative ability training is very significant. In this paper, the construction of students' innovation and entrepreneurship education system was discussed to explore new approaches for innovation and entrepreneurship education.
\end{abstract}

\section{Introduction}

Innovation and entrepreneurship education intends to cultivate basic quality and skills of college students necessary for innovation and entrepreneurship. It is a component of quality education for college students, and also a part of adapting to current social and economic development and constructing national innovation system. Till now, innovation and entrepreneurship education did not receive due attention from Chinese colleges and universities, and most of them did not incorporate innovation and entrepreneurship education into teaching system, lacking of mature theory system and operable teaching methods. However, social development has raised the requirements that we must carefully study and improve the innovation and entrepreneurship education system in colleges and universities.

\section{Incorporating Innovation and Entrepreneurship Education into Teaching System}

In the "Notice of Making Good Arrangements for Employment and Entrepreneurship of 2016 National College Graduates", the Ministry of Education proposed again to "strengthen the innovation and entrepreneurship education and self-employment". Chinese innovation and entrepreneurship education, especially for college students, just got attention in recent years. Colleges and universities have very one - sided understanding to innovation and entrepreneurship education, with utilitarian targets and single course system, which do not agree with the requirements of cultivating innovative and entrepreneurial talents. The innovation education of university, entrepreneurship training as well as innovation practice and entrepreneurial environment of University Science Park are integrated to make uniform planning in respects of teaching methods, curriculum arraignment, innovation ability training and job training, so as to establish an improved education system for cultivating innovative talents. Students are cultivated for a whole process from theoretical teaching, academic research, research activities, entrepreneurship training and entrepreneurial practice. A diversified curriculum construction and management system is established in combination of basic theory teaching, specialized courses teaching and entrepreneurial practice guidance.

The cultivation of innovative and entrepreneurial talents is different from the traditional education mode both in education concept and teaching mode. Innovation and entrepreneurship education is very important for the cultivation of students' spirit of scientific exploration, innovative awareness of science and technology, self-employment ability as well as management skills and social activity ability. Taking the cultivation of innovative and entrepreneurial spirit and skill as one of the functions, colleges and universities must raise the status of innovation and entrepreneurship 
education to a level of teaching research and academic research, going through the whole process of academic education. Teaching program for innovation and entrepreneurship will be formulated in the teaching system to integrate and interinfiltrate specialized education and the innovation and entrepreneurship education. A complete innovation and entrepreneurship curriculum system is established in terms of curriculum arrangement, contents design and curriculum system design. Teaching and practice are combined by the multi-level and three-dimensional curriculum structure design to train the individual thinking of students and explore forms of education and teaching in addition to general education. Relying on University Science Park, Students Entrepreneurship Park, science and technology business incubators and other conditions, university laboratories, laboratory equipment and other resources are open to students to create entrepreneurship practice platform. By combination of theory teaching, practical teaching and social practice, students' innovative and entrepreneurial ability is effectively improved in practice, truly implementing the innovation and entrepreneurship education.

\section{Emphasizing on Cultivation of Students' Innovative and Entrepreneurial Consciousness and Ability}

Innovation and entrepreneurship education itself is exploring and searching for development rules in a changing social environment. The teaching mode of colleges mainly in imparting knowledge cannot adapt to the current innovation and entrepreneurship education. In the teaching process led by teachers, students are passive recipients of knowledge. If students are not guided to explore social practice, their innovative spirit and entrepreneurial ability will be seriously affected[1-4].

As a prerequisite for college students to step into society, innovative spirit and entrepreneurial ability are very important in the process of college education. In addition to classroom teaching, students can participate in academic lectures and the research work of teachers, and also carry out academic discussions and scientific research with teachers to improve the students' interest and ability of innovative research. Various innovation and entrepreneurship seminars are developed to convert the passive employment of some capable students to active entrepreneurship. A variety of innovation and entrepreneurship competitions are organized and students are supported to establish innovation and entrepreneurship associations and clubs, so as to encourage college students to enhance awareness of innovation and entrepreneurship through innovation and entrepreneurial activities. Positive models are established and successful cases are propagated to create the atmosphere of innovation and entrepreneurship. Successful young entrepreneurs are invited to sit together with students for a face to face communication, stimulating the enthusiasm of college students for innovation and entrepreneurship.

The reform of innovation and entrepreneurship education in colleges and universities is taken as a breakthrough to promote the coordinated development of talents cultivation and social needs, and explore the establishment of demand-oriented specialized discipline structure and new system of innovative and entrepreneurial talents cultivation. Various social resources advantages are integrated making use of University Science Parks. Entrepreneurs and entrepreneurship resources are introduced into colleges and universities to provide a good platform for the study and practice of students' innovation and entrepreneurship and cultivate their innovation ability. In enterprises of University Science Park, students can participate in internships and training to experience in the operation and management of enterprises, understand the social environment in practice, and enhance their entrepreneurial awareness and confidence. Students participate in the construction and management of entrepreneurship incubators by various forms to learn and understand the entrepreneurial process and accumulate entrepreneurial experience, bringing vitality into the entrepreneurship education and teaching activities of colleges and universities.

\section{Constructing Innovative and Entrepreneurial Talents Cultivation Bases with University Science Park as Carrier}

The construction of talents cultivation base is an important component of innovative and 
entrepreneurial talents cultivation system, functioning as assisting students to carry out entrepreneurship practice and cultivating students' ability to start a business. University Science Park is a research and development platform and a scientific and technological enterprise incubator, which is constructed based on the advantages of the specialty, talents as well as scientific and technological resources of university, with good research conditions and strong sense of innovation. As an important platform for the cultivation of scientific and technological talents, it has the excellent entrepreneurial conditions and perfect entrepreneurship service system. Innovation and entrepreneurship learning and practice base is set up in University Science Park to conduct education to students with typical cases of entity entrepreneurship. Students go to the enterprises in University Science Park for internship and practice. On the platform of high-tech enterprises, students can understand the social demand and improve their quality in university, accumulating experience for future innovation and entrepreneurship, and growing in personal experience.

The construction of student's innovation and entrepreneurship education base on the platform of University Science Park has been demonstrated by practice. In 2010, the "Opinions about Vigorously Promoting Innovation and Entrepreneurship Education in Colleges and Universities and College Students' Self Employment” was issued by the Ministry of Education. 11 national universities, including Tsinghua University, were selected as the pilot of "Practice Base for Science and Technology Entrepreneurship of Students", and achieved very good results. As a local school, the University Science Park under Changchun University of Science and Technology was approved by the Ministry of Education and Ministry of Science and Technology as a national "Practice Base for Science and Technology Entrepreneurship of Students" in 2014. In the practice of student's innovation and entrepreneurship education, school and the science park cooperate to achieve the goal of constructing innovative and entrepreneurial talents cultivation base. It plays a positive role in cultivating students' innovative spirit, strengthening entrepreneurial awareness and the ability of innovation and entrepreneurship, and promoting high quality employment and entrepreneurship of graduated students.

\section{Strengthening Entrepreneurship Incubation Function of University Science Park}

Compared with social entrepreneurs, college students have a strong sense of innovation and research, and are relatively familiar with scientific research process and results. However, they are weaker in product development, marketing and business operation. It requires the University Science Park to strengthen the functions of incubator, improve the incubation platform management system, strengthen the incubator guidance, perfect service infrastructure, introduce intermediary service institutions, conduct entrepreneurship training, and establish public service system and instructors team, so as to help enterprises for project audit, risk assessment, product promotion and guidance. Student entrepreneurs are provided with relaxed environment and policy supports to solve financial difficulties and reduce operating costs. Especially for business led by college students, a one-to-one tracking service is offered for nanny-style incubation.

Construction of students' entrepreneurship park, small- and micro-businesses incubators are promoted in University Science Park. A number of exemplary students' entrepreneurial guidance service institutions are established to provide high-quality incubation service for college student entrepreneurs, realizing entrepreneurial guidance and service everywhere. In addition to basic property, training, industrial and commercial tax registration procedures and other services, financing services and business guidance are addressed in priority. Funds are raised by the university's or cooperative enterprise's seed fund, risk investment funds introduced on the platform of University Science Park and other channels to support the innovation and entrepreneurship of college students. Scientific and technological achievements are transferred to enterprises established by college students through technical cooperation, joint development, patent transfer and the implementation of licensing, etc. Moreover, college students that intent to start a business will be provided with project docking, property rights trading and other services. 


\section{Conclusion}

Innovation and entrepreneurship of college students is a systematic project to be improved. Students' ability of innovation and entrepreneurship will be improved by integrating existing resources in colleges and universities, strengthening the construction of students and teaching staff, and relying on the University Science Park, making contributions for promoting Manufacture in China 2025 and implementation of powerful manufacturing country strategy.

\section{References}

[1]HAN Yan-Ming, Study on Concept, Education Concept and University Concept, J.EducationalResearch.9 (2003)55-56

[2]YU Qing-Chen, XU Ping. Practical Connotation of Teaching Mode Reform in Modern Classroom: A Reflection Perspective, J.Educational Science Research.1 (2014)15-18

[3]GUO Yu-Lian. Discussion on Reform of Teaching Mode in Classroom, J. Theory and Practice of Education.10(2012)57-60

[4]ZHU Hong. Research on Teaching Mode of College Classroom Reform, J. Education and Vocation.3 (2011)106-107 